\title{
Food Safety Economics in the COVID-19 Pandemic
}

\author{
Sylvain Charlebois ${ }^{1} \&$ Trevor Vandertuin ${ }^{1}$ \\ ${ }^{1}$ Agri-Food Analytics Lab, Dalhousie University, Halifax, B2X 3T5, Canada \\ Correspondence: Sylvain Charlebois, Agri-Food Analytics Lab, Dalhousie University, Halifax, B2X 3T5, \\ Canada. E-mail: Sylvain.charlebois@dal.ca
}

Received: May 14, 2021

Accepted: June 9, $2021 \quad$ Online Published: June 15, 2021

doi:10.5539/jfr.v10n4p1

URL: https://doi.org/10.5539/jfr.v10n4p1

\begin{abstract}
The consequences of the COVID-19 pandemic crisis for both food safety and especially the economic sustainability of food production in Canada and around the globe are explored. A full analysis is made of the nature of the virus, and it is spread as they relate to the forces of globalization which have created a global food supply chain, with a focus on the weaknesses of a global supply chain that fell prey to the COVID-19 virus and its associated economic effects. Comparison was made to past outbreaks of Spanish flu and Ebola, both of which challenged public health, food safety, and food supply systems. A more focused analysis examines how public and private responses to the pandemic create opportunities and challenges for several linkages in the supply chain, including farms, food processing facilities, grocery stores and restaurants. The quarantine procedures put in place around the world to manage the COVID-19 necessitated radical shifts in food production and. Ultimately the response from any individual government is insufficient to weather these events, as the fundamentally international and cross-industry factors involved require a holistic, globally coordinated approach which was not possible with the tools available before these events began.
\end{abstract}

Keywords: COVID-19, food safety, supply chain management, food economics

\section{Introduction}

At the tail end of 2019, a virus began to spread from Wuhan, China outward into the surrounding area. Carried by tourists, businesspeople, and innumerable other travellers, the virus which came to be known as COVID-19 was spread not only throughout China, but throughout the entire world, triggering a pandemic on a scale unheard of since the Spanish flu outbreak which occurred in the wake of the end of the First World War (Mallapaty, 2021).

Borders were closed, whole cities were put under quarantine, and a significant percentage of the economy of the entire world ground to a halt as governments, industry, and private individuals rushed to create and enact strategies to slow the spread of the respiratory infection and prevent a soaring death toll from increasing any further (McFadden et al., 2021). Ultimately, citizens around the world were called upon to isolate themselves in their homes to avoid contracting or transmitting the virus and, as a necessary extension, non-essential businesses of all kinds shut down (Deconinck, Avery and Jackson, 2020).

In any viral outbreak and in any natural or man-made disaster of any meaningful scale, there are consequences which extend into the realm of food. The ability of people to get enough food to sustain themselves, the ability of farmers to maintain their productive capacity and their business, the ability of food processors to remain safe and economically viable, and the ability of grocery stores, restaurants, and other purveyors of food to carry out their business are all deeply impacted by the COVID-19 outbreak (Gundersen et al., 2021). Where food intersects with public health, business, trade, and travel, COVID-19 intersects with food.

This paper, written during the ongoing COVID-19 crisis, will provide an in-depth account of the impacts of the outbreak on food through an examination of the origins of the outbreak, its effects on all food-related industries, the health risks at the intersection of the virus and food, and the structural vulnerabilities in the global food distribution system which allowed this outbreak to have such a devastating effect (Curtis et al., 2014). In addition, it will present an analysis considering the consequences of COVID-19 for vulnerable populations around the world and within the North American context as they relate to food from an intersectional perspective, with reference made to historical effects on food safety and availability for such populations during comparable crises (Goddard, 2020; Thilmany et al., 2021). 
Given the ongoing nature of the situation, the analysis, and recommendations here cannot necessarily be assumed to describe the complete scope of the situation.

\section{Historical Context}

To understand the current situation, it is helpful to consider similar situations past and how they may align or differ with the COVID-19 outbreak. The most direct correlation can be found in the Spanish flu, which spread like wildfire in the wake of the First World War. This spread is generally attributed to two factors: First World War (WWI) trench warfare and developments in transportation technology (Ellison et al., 2021).

Trench warfare saw large numbers of people stuck together in close quarters for long periods of time in extremely unsanitary conditions, which provided an ideal environment for the Spanish flu to incubate and spread within the ranks of the opposing forces. It would be when the troops returned home, however, that the flu would begin to spread globally (Dowling, 2020; Rivington et al., 2021).

While air travel was in its infancy in the later days of the First World War, rail travel was already commonplace and was the main mode of transportation for troops entering and leaving the front. Trains once again provided cramped quarters in which the virus could spread from person to person, while the disembarking troops carried the flu out to the surrounding areas where it was rapidly transmitted. The global nature of the conflict meant the flu was carried to all corners of the world. Its movement, however, was relatively slow, as it could only be carried by rail and by slow-moving ships crossing the oceans (Chappell, 2020). The scope of this spread has been mirrored by the global spread of COVID-19, but advances in transportation (notably rapid and regular air transit) have increased the speed. What might have taken months in 1918 takes days or even hours in 2020.

Spanish flu was also like COVID-19 in that it tended to cause its victims to develop pneumonia as their immune systems were compromised. However, this is one area where the current situation is better than the $20^{\text {th }}$ century crisis. COVID-19's mortality rate is significantly lower than that of the Spanish flu (Kitz et al., 2021).

What ultimately ended the Spanish flu epidemic was the development of public health policies which undermined its ability to spread. This included quarantines and more widespread access to medical services. Many of the public health policies put in place during the Spanish flu outbreak formed the base for the present-day responses to COVID-19. The necessity of these health services was largely the result of the new reality of urban life, where people were always living and working in close quarters (Le Valleé and Charlebois, 2015; Dowling, 2020). This situation is only more common in today's world as urbanization continues unchecked.

Prior to the current situation, a large-scale outbreak of Ebola in several African nations and further abroad in 2014 was met with a rapid response from international public health organizations including the World Health Organization (WHO, 2015; Walker et al., 2021). Here we can see a response from the sort of public health apparatus which arose in the wake of the Spanish flu epidemic, specifically in food safety during an epidemic. WHO provided descriptions of the symptoms and methods of transmission for Ebola to an international audience, along with instructions on how to properly prepare food to avoid transmission via food vectors (Charlebois, 2011; WHO, 2015). The use of the internet to rapidly distribute this information to affected people around the world is another advantage that modern efforts to maintain food safety and the efficacy of supply lines have over the post World War One world (Reid, Perez, and Schenker 2021).

Resources for food safety information have been even more plentiful during the current outbreak, with not only the World Health Organization, but also national entities like the US Food and Drug Administration providing detailed guidelines for maintaining safe practices when handling and preparing food. The FDA's information resources on food during the COVID-19 outbreak do not only include detailed safety guidelines for individuals and organizations, but also a detailed account of the strategies in place to manage the crisis and what should be expected regarding food availability and delivery during the ongoing situation (FDA, 2020).

\section{Pandemic Origins}

Concern regarding food safety during the pandemic first arose as news of the virus' likely origins in a Wuhan, China "wet market" began to spread widely during early 2020. It was reported that the infection originated in the Huanan seafood market in Wuhan or at another live animal market in the region, from which it spread throughout China's Hubei province in the early days of the outbreak (Readfeam, 2020).

This is not the first time a widespread outbreak of a coronavirus type infection has likely originated in a Chinese "wet market". Both COVID-19 and SARS, which was at the centre of a large-scale public health crisis in 2003, likely originated in bats, which transmitted the infection to other animals which then transmitted it to humans via these wet markets (Woodward, 2020). Here we see the first and most crucial intersection between the COVID-19 
crisis and food safety.

The structure of a wet market sees numerous different live and dead animals kept in close quarters along with large numbers of human shoppers interacting with and consuming the animals. This provides a perfect environment for viruses like COVID-19 and SARS, which can be transferred from animals to humans, to make the leap and rapidly spread among a large population. Animals are killed, butchered, and skinned in front of prospective customers, a process which can send particles carrying infectious material into the air where they can be breathed in and spread (Krause and Gruber, 2020). This perfect storm of tightly packed people and animals in unsanitary conditions mirrors the deadly combination of close quarters and lack of proper sanitation that allowed Spanish flu to spread so effectively in the trenches of WWI.

On January 12020 , the Huanan seafood market was shut down and wet markets across China followed suit as a permanent ban on the loosely regulated markets was put into place by the Chinese government. Further, the government made a commitment to crack down on illegal markets and the illegal farming of many of the species (Slaoui and Hepburn, 2020).

Despite the measures directly targeting the wet markets and associated industries, it is still unknown exactly how the virus was transmitted to humans. Understanding how this virus jumped species is crucial to mitigating the risk of future outbreaks, but scientists are still unsure precisely which animal in which location transmitted it to humans (Guo et al. 2020). Passage through food is possible, but several interactions with several different species (pangolins being one suggestion) are possible origins to the jump to humans as COVID-19 travels easily from one species to another. This is evidenced by a tiger in a New York Zoo becoming infected within the early weeks of the outbreak. SARS was transmitted from bats to a cat-like species of civets during the 2003 epidemic (Readfeam, 2020).

\section{Globalization, Food, and COVID-19}

Beyond China, steps are being taken on an international scale to prevent the spread of the virus. On March $16^{\text {th }}$ 2020, following the example of other nations, Canada closed its borders to non-essential traffic with an exemption for Americans. Canada was the first North American nation to enact a closure on this scale during the outbreak. The US, meanwhile, heavily restricted travel from affected regions (Levenson, 2020).

This response, the closure of borders, is a recognition of the primary factor which has enabled COVID-19 to reach pandemic proportions in its spread across the globe. That factor is, of course, globalization. In 1918, the First World War was an exceptional situation. It was this unusual circumstance which caused people to travel across the surface of the Earth and communicate the Spanish flu to far flung territories. In 2020, international travel is constant, normal, and global. Every condition that allowed for the Spanish flu to flourish has been multiplied. To understand how, we must examine the global supply chain and the broader effects of globalization within the context of COVID-19 (Hailu, 2020).

It is not constructive to be alarmist about the challenge's globalization poses for food safety, nor to leave the suggestion that globalization is a force which should be resisted to prevent pandemics of this nature (McCabe and Erdem, 2021). The World Health Organization recognizes several significant benefits which are afforded to nations that are integrated into the global food trade. First and foremost, the diversity of foods which can be rapidly delivered anywhere in a globalized world allows for greater nutrition and more robust public health by introducing a broad variety of food and higher quality food to consumers. Secondly, food trade provides a valuable economic boon to participating nations, allowing developing states to monetize agriculture in a way that can accelerate their development and ensure a higher standard of living for their citizens (WHO, 2014).

There are, however, significant challenges in maintaining standards of quality for food on the international market. The $21^{\text {st }}$ century has seen a sharp increase in recalls of food, despite domestic measures for detecting disease becoming steadily more advanced (Maras, 2015). This increase also comes despite agreements like the World Trade Organization (WTO, 2014) Agreement on the Application of Sanitary and Phytosanitary Measures, which created rules for member states regarding food safety in the global market.

A survey by Swiss Reinsurance Company Ltd. found that by 2015, the number of annual food recalls in the US had doubled when compared to the number of recalls in 2002. The survey ultimately concluded that the globalization of the food supply chain made risk management for food recalls significantly more difficult. Multi-million-dollar hits were taken by affected firms, reflecting the significant financial risk which comes with the economic benefits of global food trade (Maras, 2015).

The economic component of the global food supply chain is as much a centre of vulnerability as issues such as food quality and sanitation. Not only are the prices of foods which have become a standard part of diets 
worldwide tied to international supply and demand in such a way that fluctuations in the economy of even a few developing nations can have significant consequences for food prices worldwide, but global finance makes shocks not directly related to food strong factors in food prices and the viability of food production and processing around the world. As an example, a banking crisis in Iceland had devastating effects on seafood producers internationally due to their financing being heavily sourced from Icelandic banks (Sowinski, 2019). With small shocks having far-reaching effects in a global system, a crisis of this pandemic's nature, which has negative impacts on food production and finance around the globe, could be absolutely devastating.

\section{Supply Chain Impacts}

On a smaller scale, it is valuable to understand the effects the pandemic has had on the food supply chain through examination of the impacts on those industries that are most directly related to food. Farms, food processing facilities, restaurants, grocery stores, and food banks are the most direct points of contact between people and food and thus in this situation they become the most direct indicators of the challenges which COVID-19 creates in the realm of food.

Farms, the immediate source of food commodities, are facing several challenges during the pandemic. While the early days of the outbreak did not see Canada facing shortages of key foods, the closure of the Canadian border means that migrant workers will at best be delayed in arriving in Canada and at worst be unable to make the harvest season at all. The potential impact of this is huge, with millions of pounds of crops being harvested by migrant workers on a yearly basis (MacLeod, 2020).

The Canadian government has made an exception for temporary foreign workers, which will allow them to enter the country despite the border closure, but this exception comes with an onerous set of conditions including a 14-day quarantine period, housing which can accommodate self-isolation (including only 3 workers being allowed in housing that usually houses 40 in some areas), rigorous sanitation procedures for worker facilities, daily communication with isolated workers to ascertain whether or not they are symptomatic, and physical distancing during work (MacLeod, 2020). These measures, while probably essential to prevent the spread of the infection, create significant additional costs for farmers; costs which may be insurmountable for some. The workers will need to be paid for a full two-week period in which they will not be working, the social distancing measures will require changes to standard procedures for harvest, and the restrictions on housing will mean the cost of sheltering workers will be multiplied.

Canadian government officials reiterate that there is no shortage of food, but there are challenges regarding allocation of food from farms and food processing facilities which, until recently, served grocery stores and restaurants in consistent, but distinct ways (Martin, 2020). Demand for dairy products has plummeted due to the closure of many businesses, creating an excess of supply which farmers are reacting to by dumping large quantities of milk. Given the unique quota system Canada has, discarding milk was not expected, unlike in other countries like the United States (Charlebois et al., 2021). This is sixth time in 55 years that Dairy Farmers of Ontario has called upon dairy farmers to dispose of raw milk. This process is a part of the supply management system which governs Canadian dairy farms and ensures consistency of prices via controls on supply (BBC News, 2020). Given that the breakdown in demand is the result of restaurants and stores closing, not a lack of public desire to purchase dairy products, this event reveals an inefficiency in the way the dairy market operates under the conditions of an outbreak. The wastage of this milk could be made unnecessary with alternative modes of delivery.

Food processing facilities, the second step in the movement of food from earth to table, are also heavily affected by COVID-19 and the resulting government response. The CFIA has laid out an extensive series of guidelines for food processing facilities which aim to protect the health of employees at these facilities. As food and food packaging have not yet been documented to function as vectors for infection, employee health is the primary concern in responding to COVID-19 in food processing facilities (CFIA, 2020)

These guidelines include expanded sanitation procedures and a requirement for the social distancing measures (2 metres distance) recommended to the public to be followed by employees working at these facilities. These are just the most significant of a long list of requirements and recommendations issued by the CFIA (CFIA, 2020).

As with the guidelines for farms, there are challenges in maintaining this new standard and completing normal work procedures. Many facilities are not equipped for staff to operate at a regular distance of two metres, with machinery and floor layouts requiring workers to stay in much closer proximity despite the guidelines (CFIA, 2020). The CFIA rules allow for exceptions in these cases, but punitive action from the CFIA is not the sole motivating factor for wanting to avoid violation of social distancing. Losing workers to infection has its own economic consequences, both for continuing productivity and the ability of a facility that has been the site of an 
infection to remain in operation.

Like farms, food processing facilities have been impacted by the closure of restaurants and the need for people to eat at home. Preparing and packaging food for sale to a restaurant is a different process than preparing and packaging food for sale to a grocery store. Restaurants require bulk packages of food in large containers while individual consumers require smaller packaging. Shifting production to meet this altered demand is a challenge for processing facilities (Demetrakakes, 2020).

The aforementioned grocery stores are also naturally affected. While demand for some grocery store products rises by as much as 500\%, supplies from south of the border may not be consistent and the stores themselves pose a risk of infection not only to their own employees, but also to their customers (Hollingsworth, 2020).

Government guidelines have also been issued to grocery stores. For example, in British Columbia an extensive series of guidelines recommends expanded sanitation procedures, limits on the number of customers allowed within a store at one time, floor markings indicating appropriate routes through the store and positions to maintain social distancing, the removal of customer packaging such as reusable bags from store surfaces, turning away customers who are visibly symptomatic, and encouraging effective hygiene practices for staff. Similar measures have been taken nationwide (BC Ministry of Health, 2020). The same concerns regarding employee health that necessitate extra care at food processing facilities are also at play in grocery stores, with the additional complicating factor that grocery stores have a steady flow of new people entering interacting with staff and facilities during business hours. Unsanitary conditions within a store could spread infection to outside communities, while vice versa infection in the general populace could be transmitted to store employees.

The risks inherent in this sort of public gathering and interaction with the public spurred the closure of restaurants across Canada and the world, but business continues through avenues such as takeout and delivery which do not pose as high a risk for the public as the traditional sit-in meal.

The aforementioned risks of grocery shopping for the public have allowed restaurants to stay afloat by selling products such as bags of flour which may be sold out at grocery stores or may simply not be easily accessible to customers unwilling to risk a trip to a crowded store. As previously noted, supplies for restaurants are not the same as food supplies sold in grocery stores, so the specific nature of these products may vary when sold through these avenues. For example, a bag of flour will likely be a bulk 50-pound bag which may be divided at retail rather than the traditional 5 pound bag. This process not only allows for restaurants to remain financially solvent during a long period of closure, but also prevents wastage as food which had already been ordered before restaurants were forced to close can be sold in its raw form (Domonoske, 2020).

Despite these strategies for continuing under adverse conditions, the restaurant industry is still suffering financially, and restaurant owners are seeking financial aid from the federal government to prevent mass bankruptcies and permanent closures as they face rent and mortgage payments after a month or more without regular business. Over $90 \%$ of restaurant owners expressed grave concern regarding the situation in a poll by Restaurants Canada (Sagan, 2020).

This may truly be the COVID-19 epidemic exposing weaknesses in the food service industry that already existed, such as landlords charging unsustainably high rent and restaurants operating with immense overhead that leaves them extremely vulnerable to even small market shocks, much less a global pandemic resulting in multiple months of ongoing closures (Nunn, 2020). Radical change may be necessary for food delivery of all kinds if restaurants, which are filling the role of grocery stores for many people, are unable to operate or even survive in times of crisis.

\section{Conclusion}

Overall, the key conclusion to draw from this information is that any response must consider the global food supply chain as it relates to travel, urbanization, international business, and all other related factors in a holistic way.

It is the interconnectedness of people, nations, and institutions that allowed this virus to spread in the way it has, and food is a key part of that interconnectedness. In a world where food is shared across borders via a global system of trade, all people are eating at the same table and public health ceases to be an issue that can be confined by national borders. The food safety risk here is twofold: Food can be contaminated at several points in the supply chain and directly affect the health of consumers, and secondly, unsanitary food practices in one nation can trigger chains of infection that spread internationally. In this situation, as always, food is central to public health.

Nor can these issues be addressed without an up-to-date and holistic understanding of the food supply chain 
within national borders. The difficulties in maintaining supply and keeping people fed faced by restaurants, grocery stores, and other purveyors of food during this situation reveal how fragile a system that cannot immediately adjust to a temporary change in the consumption habits of Canadians and people the world over.

China responded to the issue of illegal farming and wet markets only after a pandemic caused by factors that had already been recognized by academics as increasing the risk of a human infection like COVID-19 had already occurred. This failure to act in advance of negative circumstances had consequences worldwide, but it cannot truly be said that this is entirely the fault of the Chinese government. The responses of other nations, while ultimately responsible, were scattered and inconsistent. Standards need to be set and enforced internationally for the safe sale, export, and consumption of food and the response measures for international public health events of this nature.

\section{References}

BBC News. (2020, April 6). Coronavirus: Why Canada dairy farmers are dumping milk. Retrieved from https://www.bbc.com/news/world-us-canada-52192190

BC Ministry of Health. (2020, March 28). Covid-19 Guidance to Retail Food and Grocery Stores. Retrieved from https://www2.gov.bc.ca/assets/gov/public-safety-and-emergency-services/emergency-preparedness-res ponse-recovery/embc/covid-materials/covid-19_guidance_to_grocery_stores_29mar2020_final.pdf

CFIA. (2020, April 7). Coronavirus disease (COVID-19): CFIA information for industry. Retrieved from https://www.inspection.gc.ca/covid-19/cfia-information-for-industry/eng/1584462704366/1584462704709

Chappell, M. J. (2020). COVID, food, and the Parable of the Shmoo. Agriculture and Human Values, 37(3), 1-594. https://doi.org/10.1007/s10460-020-10107-8

Charlebois, S. (2011). Food recalls, systemic causal factors and managerial implications: the case of Premiere Quality Foods. British Food Journal.

Charlebois, S., Bowdridge, E., Lemieux, J. L., Somogyi, S., \& Music, J. (2021). Supply Management 2.0: A Policy Assessment and a Possible Roadmap for the Canadian Dairy Sector. Foods, 10(5), 964. https://doi.org/10.3390/foods10050964

Curtis, D., Hill, A., Wilcock, A., \& Charlebois, S. (2014). Foodborne and waterborne pathogenic bacteria in selected Organisation for Economic Cooperation and Development (OECD) countries. Journal of food science, 79(10), R1871-R1876.

Deconinck, K., Avery, E., \& Jackson, L. A. (2020). Food Supply Chains and Covid-19: Impacts and Policy Lessons. EuroChoices, 19(3), 34-39. https://doi.org/10.1111/1746-692X.12297

Demetrakakes, P. (2020, March 21). How the Coronavirus is Affecting Food Processing. Retrieved from https://www.foodprocessing.com/articles/2020/how-the-coronavirus-is-affecting-food-processing/

Domonoske, C. (2020, April 13). A Pound Of Flour To Go? Restaurants Are Selling Groceries Now. Retrieved from https://www.npr.org/2020/04/13/831635629/a-pound-of-flour-to-go-restaurants-are-selling-groceries-now

Dowling, S. (2020, March 3). Coronavirus: What can we learn from the Spanish flu? Retrieved from https://www.bbc.com/future/article/20200302-coronavirus-what-can-we-learn-from-the-spanish-flu

Ellison, B., McFadden, B., Rickard, B. J., \& Wilson, N. L. W. (2021). Examining Food Purchase Behavior and Food Values During the COVID-19 Pandemic. Applied Economic Perspectives and Policy, 43(1), 58-72. https://doi.org/10.1002/aepp.13118

FDA Center for Food Safety and Applied Nutrition. (2020, April 6). Food Safety and the Coronavirus Disease 2019 (COVID-19). Retrieved from

https://www.fda.gov/food/food-safety-during-emergencies/food-safety-and-coronavirus-disease-2019-covid-19

Hailu, G. (2020). Economic thoughts on COVID-19 for Canadian food processors. Canadian Journal of Agricultural Economics/Revue Canadienne d'agroeconomie, 68(2), 163-169. https://doi.org/10.1111/cjag.12241

Goddard, E. (2020). The impact of COVID-19 on food retail and food service in Canada: A preliminary assessment. Canadian Journal of Agricultural Economics/Revue canadienne d'agroeconomie, 68(2), 157-161. https://doi.org/10.1111/cjag.12243

Guo, L., Wu, M., Zhu, Z., Zhang, L., Peng, S., Li, W., ... Chen, J. (2020). Effectiveness and influencing factors of online education for caregivers of patients with eating disorders during COVID-19 pandemic in China. 
European Eating Disorders Review, 28(6), 816-825. https://doi.org/10.1002/erv.2783

Gundersen, C., Hake, M., Dewey, A., \& Engelhard, E. (2021). Food Insecurity during COVID-19. Applied Economic Perspectives and Policy, 43(1), 153-161. https://doi.org/10.1002/aepp.13100

Hollingsworth, P. (2020, April 3). Demand for some grocery store items has surged 500 per cent: study. Retrieved from https://atlantic.ctvnews.ca/demand-for-some-grocery-store-items-has-surged-500-per-cent-study-1.4880413

Kitz, R., Walker, T., Charlebois, S., \& Music, J. (2021). Food Packaging During the COVID-19 Pandemic: Consumer Perceptions. International Journal of Consumer Studies. https://doi.org/10.1111/ijcs.12691

Krause, P. R., \& Gruber, M. F. (2020). Emergency Use Authorization of Covid Vaccines - Safety and Efficacy Follow-up Considerations. The New England Journal of Medicine, 383(19), E107. https://doi.org/10.1056/NEJMp2031373

Le Valleé, J. C., \& Charlebois, S. (2015). Benchmarking global food safety performances: the era of risk intelligence. Journal of food protection, 78(10), 1896-1913.

Levenson, E. (2020, March 16). Canada is closing its borders to foreigners, with an exception for US citizens. Retrieved from https://www.cnn.com/2020/03/16/world/canada-border-closing/index.html

McFadden, B. R., Malone, T., Kecinski, M., \& Messer, K. D. (2021). COVID-19 Induced Stigma in U.S. Consumers: Evidence and Implications. American Journal of Agricultural Economics, 103(2), 486-497. https://doi.org/10.1111/ajae.12188

MacLeod, M. (2020, April 11). Farmers warning of supply issues due to delay in arrival of migrant workers. Retrieved from https://www.ctvnews.ca/health/coronavirus/farmers-warning-of-supply-issues-due-to-delayin-arrival-of-migrant-workers-1.4892015

Mallapaty, S. (2021). Where did COVID come from? Five mysteries that remain. Nature (London), 591(7849), 188-189. https://doi.org/10.1038/d41586-021-00502-4

Maras, E. (2015, August 6). How Globalization Challenges Safety In The Food Supply Chain. Retrieved from https://www.foodlogistics.com/safety/article/12095450/how-globalization-challenges-safety-in-the-food-su pply-chain

Martin, M. (2020, April 14). Coronavirus: Challenges abound in Southwestern Ontario's vast farm belt. Retrieved from

https://lfpress.com/news/local-news/coronavirus-challenges-abound-in-southwestern-ontarios-vast-farm-belt

McCabe, S., \& Erdem, S. (2021). The influence of mortality reminders on cultural in-group versus out-group takeaway food safety perceptions during the COVID-19 pandemic. Journal of Applied Social Psychology, 51(4), 363-369. https://doi.org/10.1111/jasp.12740

Nunn, J. (2020, April 14). Restaurants will never be the same after coronavirus - but that may be a good thing. Retrieved from https://www.theguardian.com/commentisfree/2020/apr/14/coronavirus-restaurants-pandemi c-workers-communities-prices

Readfearn, G. (2020, April 12). How did coronavirus start and where did it come from? Was it really Wuhan's animal market? Retrieved from

https://www.theguardian.com/world/2020/apr/13/how-did-the-coronavirus-start-where-did-it-come-from-ho w-did-it-spread-humans-was-it-really-bats-pangolins-wuhan-animal-market

Reid, A., Rhonda-Perez, E., \& Schenker, M. B. (2021). Migrant workers, essential work, and COVID-19. American Journal of Industrial Medicine, 64(2), 73-77. https://doi.org/10.1002/ajim.23209

Rivington, M., King, R., Duckett, D., Iannetta, P., Benton, T. G., Burgess, P. J., ... Keay, C. (2021). UK food and nutrition security during and after the COVID-19 pandemic. Nutrition Bulletin, 46(1), 88-97. https://doi.org/10.1111/nbu.12485

Sagan, A. (2020, March 21). Restaurants seek gov't help to stay afloat amid COVID-19 shutdowns. Retrieved from https://www.ctvnews.ca/health/coronavirus/restaurants-seek-gov-t-help-to-stay-afloat-amid-covid-19-s hutdowns-1.4862603

Slaoui, M., \& Hepburn, M. (2020). Developing Safe and Effective Covid Vaccines - Operation Warp Speed's Strategy and Approach. The New England Journal of Medicine, 383(18), 1701-1703. https://doi.org/10.1056/NEJMp2027405 
Sowinski, L. L. (2019, August 16). The Global Food Supply Chain. Retrieved from https://www.foodlogistics.com/technology/article/10657347/the-global-food-supply-chain

Thilmany, D., Canales, E., Low, S. A., \& Boys, K. (2021). Local Food Supply Chain Dynamics and Resilience during COVID-19. Applied Economic Perspectives and Policy, 43(1), 86-104. https://doi.org/10.1002/aepp.13121

Walker, T. R., McGuinty, E., Charlebois, S., \& Music, J. (2021). Single-use plastic packaging in the Canadian food industry: consumer behavior and perceptions. Humanities and Social Sciences Communications, 8(1), 1-11. https://doi.org/10.1057/s41599-021-00747-4

WHO. (2014, June 13). Food safety and globalization of trade in food. Retrieved from https://www.who.int/foodsafety/publications/globalization-trade-food/en/

WHO. (2015, June 21). Information note: Ebola and food safety. Retrieved from https://www.who.int/csr/disease/ebola/note-ebola-food-safety/en/

Woodward, A. (2020, February 26). Both the new coronavirus and SARS outbreaks likely started in Chinese wet markets. Photos show what the markets look like. Retrieved from

https://www.businessinsider.com/wuhan-coronavirus-chinese-wet-market-photos-2020-1

\section{Copyrights}

Copyright for this article is retained by the author(s), with first publication rights granted to the journal.

This is an open-access article distributed under the terms and conditions of the Creative Commons Attribution license (http://creativecommons.org/licenses/by/4.0/). 